\title{
SISTEM INFORMASI PENJUALAN BERBASIS ANDROID BAGI UKM RETAILER DI KELURAHAN KANDANG LIMUN KOTA BENGKULU
}

\section{ANDROID BASED OF SALES INFORMATION SYSTEM FOR SMALL SCALE RETAILER ENTERPRISESIN KANDANG LIMUN BENGKULU CITY}

\author{
Oleh: \\ Apri Andani ${ }^{1)}$, Basuki Sigit Priyono ${ }^{2)}$, Rusdi Efendi ${ }^{3)}$ \\ ${ }^{1,2)}$ Jurusan Sosial Ekonomi Pertanian, Fakultas Pertanian, Universitas Bengkulu \\ ${ }^{3)}$ Jurusan Teknik Informatika, Fakultas Teknik, Universitas Bengkulu \\ Email: apriandani82@gmail.com
}

\begin{abstract}
The purposes of this community service are to improve SME's owner's skill in using simple technology for their business and to amend their inventories and sales management by using Android Management Information System Application. This community service was conducted in Kandang Limun, Bengkulu City, in 2017. The target society was the owners of SME retails around location. There were 15 owners of SME retails. The methods used were persuasive approach, demonstrations and practices, accompaniment, and evaluation. The content of training were simple financial report recording and $i$-REAP and Barcode application by Android. The result shows that this activity was done well. Each step was followed seriously by the participants. After training, 50\% of the owners still applied simple accounting recording, 30\% owners used i-REAP, and 20\% owners used both. Finally after accepting this training, 100\% owners who used both manual accounting recording and $i$-REAP were able to know the amount of goods inventory and sales better than before accepting the training.
\end{abstract}

Keywords: android, sales information system, $i-R E A P$

\section{PENDAHULUAN}

Pertumbuhan penduduk tentu akan memacu pola konsumsi yang lebih banyak dan beragam di masyarakat. Hal ini yang kemudian memicu munculnya usaha-usaha dagang yang menjual kebutuhan-kebutuhan dasar masyarakat tadi, baik dengan skala besar seperti supermarket (Giant dan Hypermart), ataupun minimarket skala nasional seperti Alfamart dan Indomaret. Tidak ketinggalan pula akan tumbuh usaha-usaha dagang eceran atau biasa disebut usaha retail skala kecil dan menengah (UKM). Demikian juga halnya di Kota Bengkulu, khususnya di sekitaran kawasan Universitas Bengkulu.

Dalam satu tahun terakhir, pertumbuhan usaha retail minimarket skala nasional di sekitar kampus Unib sangat pesat. Setidaknya ada empat store muncul di tahun 2017 (baru enam bulan), yaitu 2 toko Alfamart dan 2 toko Indomaret di sekitar Unib. Ditambah lagi minimarket lokal skala sedang, yaitu El-Jhon. Sementara Minimarket Extra merupakan pengusaha lama. 
Keberadaan minimarket-minimarket tersebut tentunya semakin memberi kemudahan kepada konsumen untuk mendapatkan barang yang lebih variatif dari segi kualitas dan harga. Disamping itu, tawaran pelayanan yang diberikan membuat konsumen mendapatkan barang yang dibutuhkan lebih cepat karena dibantu dengan mesin kasir otomatis, dan tidak kuatir dengan harga barang karena setiap item barang telah diberi label harga yang jelas.

Bagi konsumen, keberadaan minimarket-minimarket tadi tentu sangat membantu mereka dalam memenuhi kebutuhan sehari-harinya. Namun bagi pengusaha retail UKM rumah tangga biasa, kehadiran Alfamart, Indomaret, dan El-Jhon tentu menjadi ancaman karena akan mengurangi pelanggan yang selama ini berbelanja di "warung" mereka. Tentu konsumen lebih rasional dalam memilih tempat belanja. Mereka akan memilih tempat yang nyaman, menawarkan kecepatan transaksi, serta kemudahan dalam mendapatkan informasi harga, yang tidak pernah didapatkan di warung retail biasa.

Pelayanan-pelayanan yang serba lebih baik dari Alfamart, Indomaret, serta El-Jhon tidak terlepas dari pemanfaatan teknologi informasi guna mendukung setiap proses transaksi pembelanjaan yang ada pada usaha retail mereka. Transaksi pembayaran konsumen untuk setiap barang yang dibeli sudah dilakukan dengan menggunakan masin kasir otomatis yang membuat proses pembayaran lebih cepat, meskipun jumlah barang yang dibeli relatif banyak. Disamping itu, teknologi ini tentu sangat membantu pengelola usaha dalam melakukan pencatatan penjualan dan persediaan barang, bahkan sampai pada penghitungan rugi-laba usaha. Akses terhadap teknologi ini yang tidak dimiliki oleh pemilik usaha retail skala UKM atau rumah tangga.

Rendahnya akses terhadap teknologi di masa perkembangan teknologi yang sangat pesat, tentu menjadi kelemahan tersendiri bagi individu maupun perusahaan, termasuk usaha kecil menengah (UKM). Ketika usaha-usaha dagang (retailer), seperti Alfamart, Indomaret, dan El-Jhon juga Extra sudah memanfaatkan teknologi informasi dalam manajemen informasi penjualan, yaitu dengan menggunakan mesin kasir otomatis, pedagang eceran rumah tangga masih dengan catatan manual, bahkan ada yang tidak melakukan pencacatan sama sekali. Sebagian beranggapan tidak mampu membeli dikarenakan harganya yang mahal, komputer dan software-nya, sebagian menyatakan bahwa tidak paham dengan teknologi komputer, dan sebagian lagi menganggap tidak begitu penting. Padahal pemanfaatn teknologi tersebut dapat membantu perusahaan tidak hanya dalam melayani transaksi penjualan kepada pembeli saja, melainkan juga basis data informasi persediaan sampai kepada laporan rugi laba usaha.

Ketidakmauan dan ketidakmampuan dalam mengakses teknologi tersebut menjadikan usaha retail skala rumah tangga menjadi ditinggalkan, tidak saja oleh pesaing, tetapi juga oleh pembeli/konsumen. Lemahnya manajemen usaha terkait pencatatan penjualan juga akan berujung pada tidak tersedianya catatan keuangan dan informasi persediaan barang, sehingga pengambilan keputusan usaha juga sering tidak tepat.

Oleh karena itu dibutuhkan teknologi yang dapat dijangkau baik dari segi harga maupun kemudahannya, namun tetap memberikan manfaat yang sama besarnya dengan teknologi yang digunakan oleh retailer sekelas Alfamart.

Menurut ITTA (Information Technology Association of America), pengertian Teknologi Informasi adalah suatu studi, perancangan, implementasi, pengembangan, dukungan atau manajemen sistem informasi berbasis komputer, terkhususnya pada aplikasi perangkat lunak komputer. Teknologi informasi memanfaatkan komputer elektronik dan perangkat lunak komputer untuk mengubah, menyimpan, memproses, melindungi, mentransmisikan dan memperoleh informasi secara aman (Sutarman, 2009). 
Sutarman (2009) menjelaskan lebih lanjut tentang fungsi teknologi informasi yaitu menghasilkan atau mengorganisasikan informasi ke dalam bentuk yang berguna, misalnya laporan, tabel, grafik, dan sebagainya.

Menurut Haaq dan Keen dalam Kandunk (2014), Teknologi Informasi didefinisikan sebagai seperangkat alat yang membantu bekerja dengan informasi dan melakukan tugastugas yang berhubungan dengan pemrosesan informasi.

Latifwindar (2015) berpendapat bahwa saat ini aplikasi teknologi informasi dalam praktek bisnis telah memberikan hasil yang positif terhadap dunia bisnis, dimana para pelakunya dapat bersaing dengan para kompetitor dan dapat diterima oleh pasar secara global. Peran dari teknologi informasi bisnis adalah dapat mengintegrasikan semua proses bisnis, mulai dari pemasaran, keuangan, operasional, sumberdaya manusia, sampai pada proses perencanaan dan pengembangan bisnis. Salah satunya adalah sistem informasi penjualan (kasir).

Sistem informasi penjualan adalah suatu sistem informasi yang mengorganisasikan serangkaian prosedur dan metode yang dirancang untuk menghasilkan, menganalisa, dan memperoleh informasi guna mendukung pengambilan keputusan bisnis (Ladjamudin, 2005). Contoh sistem informasi penjualan yang dapat diakses melalui telepon genggam berbasis Android adalah aplikasi iREAP.

iREAP adalah singkatan dari Integrated Retail Application, adalah suatu aplikasi yang dirancang dan dikembangkan untuk membantu pelaku bisnis dalam mengatur dan menjalankan operasional took yang terdiri dari Point of Sales/Sistem Kasir dan Sistem Pengelolaan Barang (Anonim, 2017).

Dalam menjalankan fungsinya, aplikasi iREAP dibantu oleh aplikasi berbasis Android lainnya, yaitu Barcode Scanner. Barcode Scanner adalah alat yang digunakan untuk membaca kode-kode berbentuk garis-garis vertical (disebut dengan Barcode) yang terdapat pada kebanyakan produk produk-produk consumer good (Pusat Barcode, 2008). Keuntungan yang diperoleh dalam penggunaan Barcode Scanner yang pertama adalah memperkecil kesalahan input yang disebabkan oleh kesalahan operator komputer atau kasir, dan keuntungan lainnya adalah Barcode Scanner mempercepat proses input data, sehingga mengurangi jumlah antrian yang panjang.

Tanpa barcode, dahulu kasir memasukkan penjualan di computer dengan bantuan nama barang atau kode barang. Nama barang memang dirasa lebih memperkecil kemungkinan kesalahan, namun kerugiannya adalah waktu entry akan sangat lama karena kasir akan mengetikkan lebih banyak karakter.

Perkembangan teknologi yang cepat dan ditawarkan dengan harga yang terjangkau sangat memungkinkan bagi setiap orang untuk mengakses teknologi-teknologi tersebut dengan mudah, salah satunya adalah telepon genggam pintar atau sering disebut dengan Smartphone. Smartphone tentu saja tidak hanya menawarkan kemampuan untuk menelepon dan berkirim pesan singkat biasa. Diberi julukan telepon genggam pintar, tentu ada penyebabnya. Banyak hal yang dapat dilakukan dengan satu smartphone saja. Mulai dari panggilan video, penyediaan layananan email, sampai pada penyediaan aplikasiaplikasi modern dan bermanfaat lainnya.

Salah satu aplikasi yang dapat diinstal dari Smartphone adalah iREAP dan Barcode Scanner yang disediakan oleh Smartphone dengan sistem operasi Android. Aplikasi ini memiliki kinerja yang hampir sama persis dengan mesin kasir yang digunakan oleh retailer besar seperti Hypermat, Giant, ataupun Alfamart dan Indomaret, yang membedakan hanya dari aspek kapasitas data yang mampu disimpan yang tergantung pada ketersediaan memory data di smartphone yang dimiliki oleh pengguna. 
Aplikasi iREAP dan Barcode Scanner bisa menjadi solusi atas mahalnya teknologi mesin kasir dan susahnya memahami teknologi yang dianggap "ribet" oleh pemilik UKM retailer. Selain murah karena dapat diunduh secara gratis melalui HP android, aplikasi ini juga sangat mudah dalam penggunaannya. Sistem aplikasi ini bekerja layaknya sebuah mesin kasir otomatis yang langsung menghitung transaksi penjualan, menyimpan data pembelian barang, mengelola persediaan barang, sampai pada kemampuan untuk menghitung rugi/laba usaha selama periode tertentu yang dikehendaki oleh pengguna. Sehingga pengguna tidak lagi memerlukan catatan manual atau bahkan perlahan mulai meninggalkan kebiasaan tidak memiliki catatan apa-apa terkait pengelolaan usaha dagangnya.

Pengabdian ini diharapkan mampu menjadi sarana yang dapat mengurangi ketertinggalan UKM retail yang ada di sekitar kawasan kampus Unib dengan pengusahapengusaha retail yang lebih besar dan modern. Dengan model teknologi yang sederhana dan tersedia di HP yang dimiliki oleh pemilik usaha retail rumah tangga, program pengabdian ini seharusnya menjadi lebih mudah untuk diterapkan. Pengabdian juga akan menjadi sarana penerapan ilmu pengetahuan yang dimiliki oleh institusi Unib kepada masyarakat sekitar kampus.

Adapun tujuan dari kegiatan pengabdian pada masyarakat ini adalah untuk:

a. Meningkatkan kemampuan UKM Retailer dalam memanfaatkan teknologi sederhana untuk kepentingan usaha.

b. Memperbaiki manajemen persediaan dan penjualan UKM Ratailer melalui penerapan aplikasi sistem informasi penjualan berbasis android.

Kegiatan pengabdian ini diharapkan dapat memberikan manfaat berupa:

1. Peningkatan kemampuan pemilik UKM retail dalam mengakses teknologi sehari-hari sederhana yang dapat digunakan untuk kelancaran transaksi usahanya.

2. Program pengabdian menjadi wadah bagi dosen untuk menerapkan ilmu pengetahuan dan teknologi yang dimiliki kepada masyarakat umum.

\section{METODE PENGABDIAN}

Masyarakat yang menjadi khalayak sasaran program pengabdian masyarakat berbasis penerapan IPTEKS ini adalah para Pemilik UKM Retail Sembako yang ada di sekitar kampus Universitas Bengkulu, tepatnya yang memiliki usaha di Jl. W.R. Supratman Kelurahan Kandang Limun, Kecamatan Muara Bangkahulu, Kota Bengkulu. Ada 15 orang pemilik UKM retail yang diundang untuk mengikuti kegiatan pengabdian ini. Pertimbangan dalam memilih khalayak sasaran tersebut adalah mereka yang tidak memiliki catatan pembukuan keuangan usaha dikarenakan rendahnya pengetahuan atau dianggap terlalu merepotkan, sedangkan skala usaha tidak begitu besar.

Metode yang akan digunakan demi menunjang keberhasilan kegiatan ini adalah:

1. Metode pendekatan persuasif

Cara ini dilakukan melalui penyuluhan formal yang berisi materi-materi pengabdian, dalam hal ini adalah Sistem Informasi Penjualan berbasis Android, yaitu iREAP dan Barcode Scanner. Dalam pengabdian kali ini, penyuluhan dilakukan hanya dalam satu kali pertemuan saja. Aktivitas pengabdian akan lebih banyak diarahkan pada praktik penggunaan Sistem Informasi Penjualan berbasis Android, yaitu iREAP dan Barcode Scanner.

2. Pendekatan kedua yaitu demonstrasi dan praktek 
Metode ini dilakukan setelah adanya pembekalan melalui tahapan penyuluhan. Tahapan kedua yang akan dilakukan adalah pelatihan. Pelatihan dilaksanakan melalui 2 tahapan, yaitu:

a. Tahap Pra Sistem: Penerapan Pencatatan Keuangan Manual ke Dalam Buku Kas Folio yang telah disiapkan oleh Tim Pengabdian

b. Tahap I: Praktik penginstalan aplikasi iREAP dan Barcode Scanner di Handphone para khalayak sasaran yang memiliki basis operasi Android.

c. Tahap II: Praktik penggunaan aplikasi iREAP dan Barcode Scanner dengan data simulasi usaha penjualan retail.

d. Tahap III: Praktik penggunaan aplikasi iREAP dan Barcode Scanner dengan menggunakan data asli barang dagangan UKM retail yang menjadi khalayak sasaran.

3. Pendampingan

Metode pendampingan dilakukan dengan sistem pengawasan rutin terhadap penggunaan sistem aplikasi iREAP yang telah diberikan. Pengawasan dilakukan untuk memastikan bahwa setiap UKM yang dibina benar-benar menerapkan teknologi yang telah disampaikan. Hal ini ditujukan untuk melihat tingkat efektivitas program pengabdian yang dilakukan, apakah memberikan manfaat bagi UKM-UKM tersebut atau tidak.

4. Evaluasi

Evaluasi merupakan proses yang sistematis dan berkelanjutan untuk mengumpulkan, mendeskripsikan, menginterpretasikan, dan menyajikan informasi untuk dapat digunakan sebagai dasar membuat keputusan, menyusun kebijakan, maupun menyusun program selanjutnya. Evaluasi bertujuan untuk memperoleh informasi yang akurat dan objektif tentang suatu program. Informasi tersebut dapat berupa proses pelaksanaan program, dampak/hasil yang dicapai, efisiensi serta pemanfaatan hasil evaluasi yang difokuskan untuk program itu sendiri, yaitu untuk mengambil keputusan apakah dilanjutkan, diperbaiki atau dihentikan.

Ada banyak model evaluasi yang dikembangkan oleh para ahli yang biasa dipakai dalam mengevaluasi program pelatihan. Salah satu model evaluasi yang tepat digunakan dalam pengabdian ini adalah Model Kirkpatrick (Kirkpatrick, 1998). Ada 4 (empat) level evaluasi dalam model ini, yaitu: lebel 1 -Reaction, level 2 - Learning, level 3 -Behavior, level 4 - Result.

Pada level pertama, evaluating reaction, nantinya akan dievaluasi bagaimana reaksi khalayak sasaran terhadap pelatihan/penyuluhan yang diberikan, apakah puas atau tidak, sehingga akan terlihat ada atau tidaknya motivasi mereka untuk belajar dan berlatih tentang materi pengabdian. Kepuasan peserta penyuluhan dan pelatihan dapat dikaji dari beberapa aspek, yaitu materi yang diberikan, fasilitas yang tersedia, cara penyampaian materi, media pembelajaran, jadwal kegiatan, dan sarana penunjang lainnya. Level kedua, evaluating learning, merupakan level dimana instruktur dapat mengajarkan pengetahuan, sikap, dan keterampilan. Pada level ini, hal yang dapat dievaluasi adalah (i) pengetahuan apa yang telah dipelajari? (ii) sikap apa yang telah berubah? Dan (iii) keterampilan apa yang telah dikembangkan atau diperbaiki?

Level selanjutnya adalah behavior, atau tingkah laku. Hal yang bisa dievaluasi pada level ketiga ini adalah apakah khalayak sasaran merasa senang setelah mengikuti program dan kembali ke aktivitas usahanya? Bagaimana khalayak sasaran dapat mentransfer pengetahuan, sikap, dan keterampilan yang diperoleh selama program untuk diterapkan di usahanya? 
Terakhir adalah level evaluating result. Level ini berorientasi pada hasil akhir pelaksanaan program setelah peserta mengikuti program pengabdian ini. Dalam program pengabdian kali ini, yang termasuk ke dalam hasil akhir adalah UKM Retailer di sekitar Kelurahan Kandang Limun menggunakan sistem informasi penjualan berbasis android, yaitu aplikasi iREAP, dalam aktivitas usahanya seharihari.

\section{HASIL DAN PEMBAHASAN}

\section{Tahap Penyuluhan}

Penyuluhan dihadiri oleh 15 pemilik UKM retailer (pedagang kelontong) di sekitar Kelurahan Kandang Limun. Acara pelatihan diselenggarakan di kantor Kelurahan dan dihadiri juga oleh Lurah Kandang beserta jajaran dan staf kelurahan, serta anggota tim pengabdian, yaitu dosen dan mahasiswa pembantu pengabdian. Kegiatan penyuluhan berjalan dengan lancar dan peserta serius mendengarkan penyuluhan dari pemateri. Setidaknya $30 \%$ peserta penyuluhan bertanya kepada narasumber yang berkaitan dengan materi. Pada sesi penyuluhan ini, materi pengabdian yang disampaikan adalah Pembukuan Keuangan Sederhana dan Pengenalan i-REAP. Penyuluhan menggunakan alat bantu infocus dan powerpoint serta fotokopian materi yang dibagikan kepada setiap peserta yang hadir. Sebagian besar peserta pemilik UKM retailer berjenis kelamin perempuan. Dari hasil diskusi memang didapat informasi bahwa aktivitas mengelola bisnis di sekitar rumah merupakan cara perempuan untuk mengisi kekosongan waktu sekaligus dapat membantu pemenuhan kebutuhan keluarga. Namun ada juga yang menyatakan bahwa berjualan merupakan mata pencaharian utama keluarga. Tidak hanya istri saja, tetapi suami juga ikut berperan dalam menjalankan usaha dagangnya. Sesi penyuluhan ini hanya sebatas memberikan informasi, sedangkan aspek demonstrasi dan prakteknya akan disampaikan pada sesi pelatihan yang dilakukan pada tahap berikutnya. Berikut beberapa dokumentasi kegiatan penyuluhan.
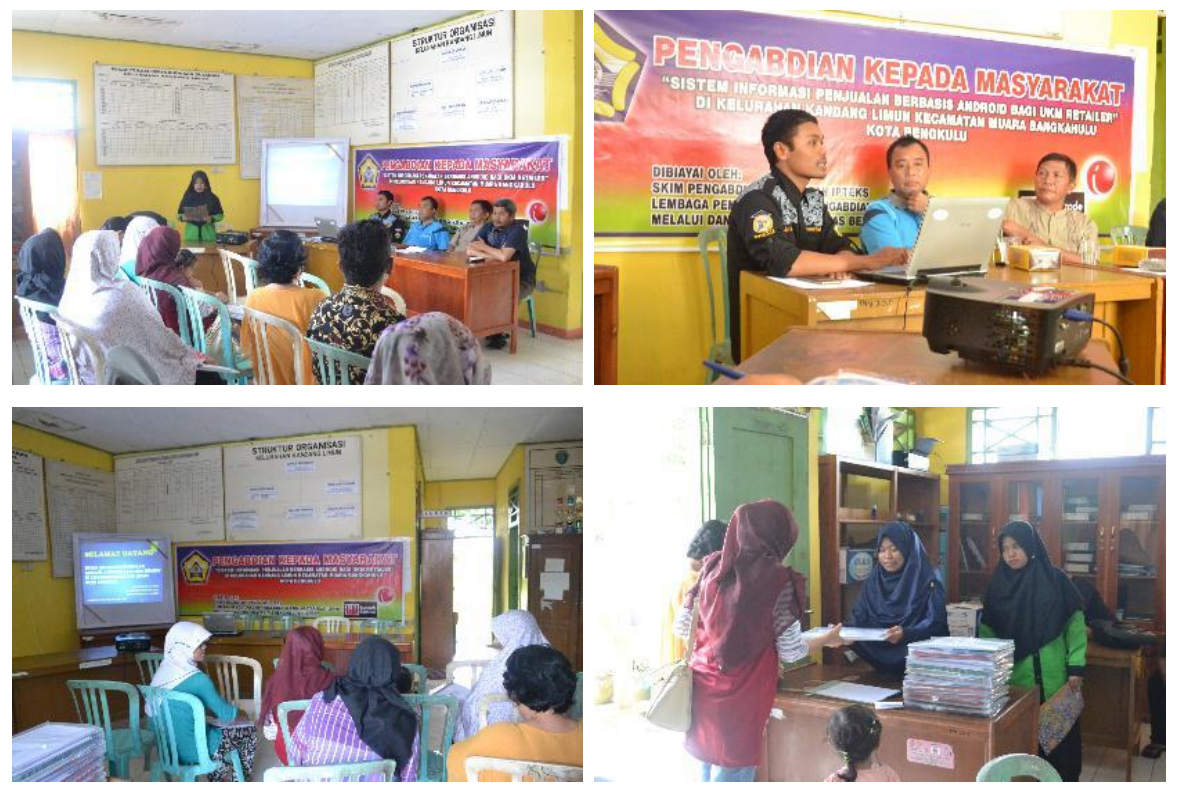

Gambar 1. Kegiatan penyuluhan 


\section{Tahap Pelatihan}

Pada tahapan ini, pelatihan dibagi ke dalam 2 sesi, yaitu sesi pelatihan pencatatan manual keuangan usaha sederhana dan pelatihan instalasi dan penggunaan aplikasi iREAP dan Barcode Scanner.

\section{Pelatihan Pembukuan Keuangan Sederhana}

Pada tahap pelatihan ini, materi yang diberikan adalah model pencatatan keuangan sederhana. Pada prinsipnya yang dilatih adalah melakukan recording terhadap transaksi uang masuk dan keluar, barang masuk dan keluar, sehingga pemilik usaha kecil retail memiliki catatan keuangan yang kemudian memudahkan mereka dalam mengelola usahanya. Dari hasil diskusi awala, semua peserta pengabdian tidak ada yang melakukan pencatatan keuangan usaha dagangnya. Umumnya keuangan usaha bercampur dengan keuangan rumah tangga. Pemilik akan mengambil uang langsung dari warung untuk membeli keperluan rumah tangga atau jajan anak. Demikian juga ketika suami butuh rokok, langsung mengambil dari warung. Tentu hal ini membuat pemilik usaha tidak tahu berapa besar penghasilan yang dia peroleh setiap harinya dari usaha berdagang. Pada sesi ini, peserta diberikan bantuan perlengkapan berupa seperangkat alat tulis dan buku portofolio akuntansi sederhana yang di dalamnya sudah disiapkan kolom-kolom pemisah untuk pengeluaran dan pemasukan usaha.

Selama pelatihan berlangsung, peserta terlihat tekun dalam mengikuti dan mencoba untuk melakukan praktek langsung. Mereka secara mandiri dan didampingi oleh beberapa mahasiswa belajar melakukan pencatatan keuangan dari contoh kasus yang diberikan oleh pemateri. Berikut adalah dokumentasi kegiatan pelatihan pencatatan keuangan sederhana.
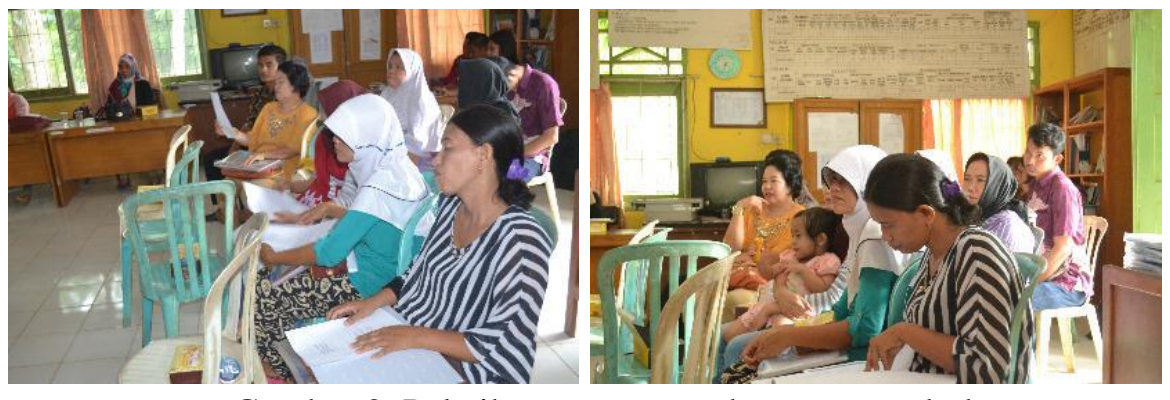

Gambar 2. Pelatihan pencatatan keuangan sederhana

\section{Pelatihan Instalasi dan Penggunaan Aplikasi iREAP dan Barcode Scanner}

Pelatihan instalasi dan penggunaan aplikasi iREAP dan Barcode Scanner dilakukan di Lab. Sosek Fakultas Pertanian Universitas Bengkulu. Materi pelatihan ini langsung disampaikan oleh anggota tim Pengabdian yang juga dosen Teknik Informatika, yaitu Bapak Rusdi Efendi, S.T., M.Kom. Pelatihan dimulai dari penyampaian materi singkat tentang aplikasi yang digunakan serta manfaatnya bagi peserta pengabdian. Kemudian dilanjutkan dengan praktek instalasi aplikasi di HP masing-masing peserta. Sebagian peserta membawa anak-anaknya guna mambantu memahami penggunaan HP dan aplikasi. Disini mahasiswa pembantu program pengabdian juga terlibat untuk mendampingi peserta selama proses instalasi aplikasi. Proses instalasi sendiri hanya memakan waktu beberapa menit saja dan semua peserta sukses melakukan penginstalan. Hal ini dikarenakan proses penginstalan yang mudah serta ukuran aplikasi yang tidak terlalu besar.

Setelah semua peserta sukses melakukan praktek instalasi, materi kemudian dilanjutkan dengan praktek penggunaan aplikasi i-REAP dan Barcode. Pada tahapan ini beberapa kesulitan dihadapi peserta, terutama yang berkaitan dengan penggunaan Barcode 
Scanner dan iREAP secara bersamaan. Kemudian kendala juga dihadapi pada saat memasukkan database barang. Sebagian peserta beranggapan bahwa hal ini memakan waktu yang cukup lama jika harus dimasukkan satu per satu. Untuk mengatasi kendala ini, pemateri langsung menjelaskan kepada peserta bahwa secanggih apapun sistem komputer tetap harus ada input data terlebih dahulu, dan itu dilakukan secara manual, setelah itu baru semua sistem bisa berjalan secara otomatis dan lebih cepat, dan akhirnya peserta mulai memahami dan melanjutkan pelatihan. Pada tahapan ini secara umum, peserta sudah memahami bagaimana menginstal dan menjalankan aplikasi iREAP dan Barcode Scnanner. Berikut beberapa foto kegiatan selama pelatihan penginstalan dan penggunaan aplikasi iREAP dan Barcode Scanner.

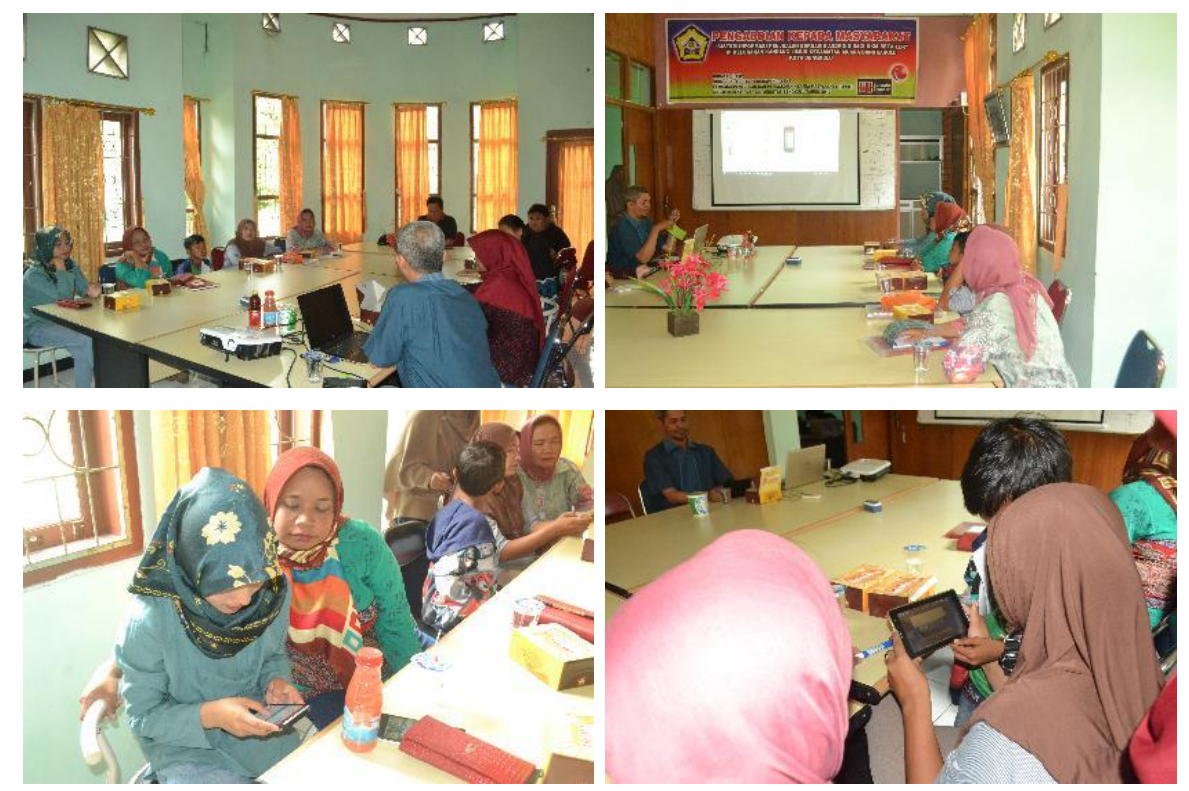

Gambar 3. Pelatihan instalasi dan penggunaan aplikasi iREAP dan Barcode Scanner

\section{Monitoring dan Evaluasi Pasca Penyuluhan dan Pelatihan \\ Monitoring}

Bentuk monitoring yang dilakukan selama pengabdian ini adalah pendampingan program pasca penyuluhan dan pelatihan. Monitoring dibantu oleh mahasiswa pendamping. Bentuk kegiatannya adalah melakukan kunjungan langsung ke lokasi usaha peserta pengabdian secara bertahap. Tahap pertama yaitu seminggu setelah penyuluhan untuk memantau apakah peserta melakukan pencatatan keuangan atau tidak sekaligus menerima keluhan dan membantu proses pencatatan jika peserta masih belum memahami dan belum sepenuhnya menerapkan. Dari hasil monitoring tahap awal ini, ditemukan 50\% peserta yang datang pada saat penyuluhan dan pelatihan sudah menerapkan pencatatan keuangan sederhana dalam buku folio kas yang diberikan oleh tim pengabdian.

Tahap kedua adalah satu minggu setelah pelatihan instalasi dan penggunaan i-Reap. Penerapan teknologi ini lebih sedikit dibanding pencatatan keuangan sederhana. Hanya $30 \%$ saja yang masih terus menggunakan aplikasi untuk mengelola warung mereka, sebagian besar $(70 \%)$ tidak menggunakan karena mereka mengganggap agak sedikit merepotkan ketika menggunakan aplikasi tersebut, apalagi terkendala dengan penggunaan HP. HP seringkali digunakan anak dan dibawa ke luar rumah, jadi pencatatan tidak dapat 
selalu dilakukan dengan smartphone, alhasil mereka hanya menggunakan buku folio kas untuk melakukan pencatatan.

Dari hasil monitoring juga ditemukan hanya $20 \%$ dari seluruh khalayak pengabdian yang menerapkan kedua teknologi secara bersamaan dalam menjalankan aktivtas usahanya. Tentu angka ini masih sangat kecil, namun jika dilihat dari perubahan yang terjadi, hal ini tentu memberikan dampak positif bagi pemilik usaha.
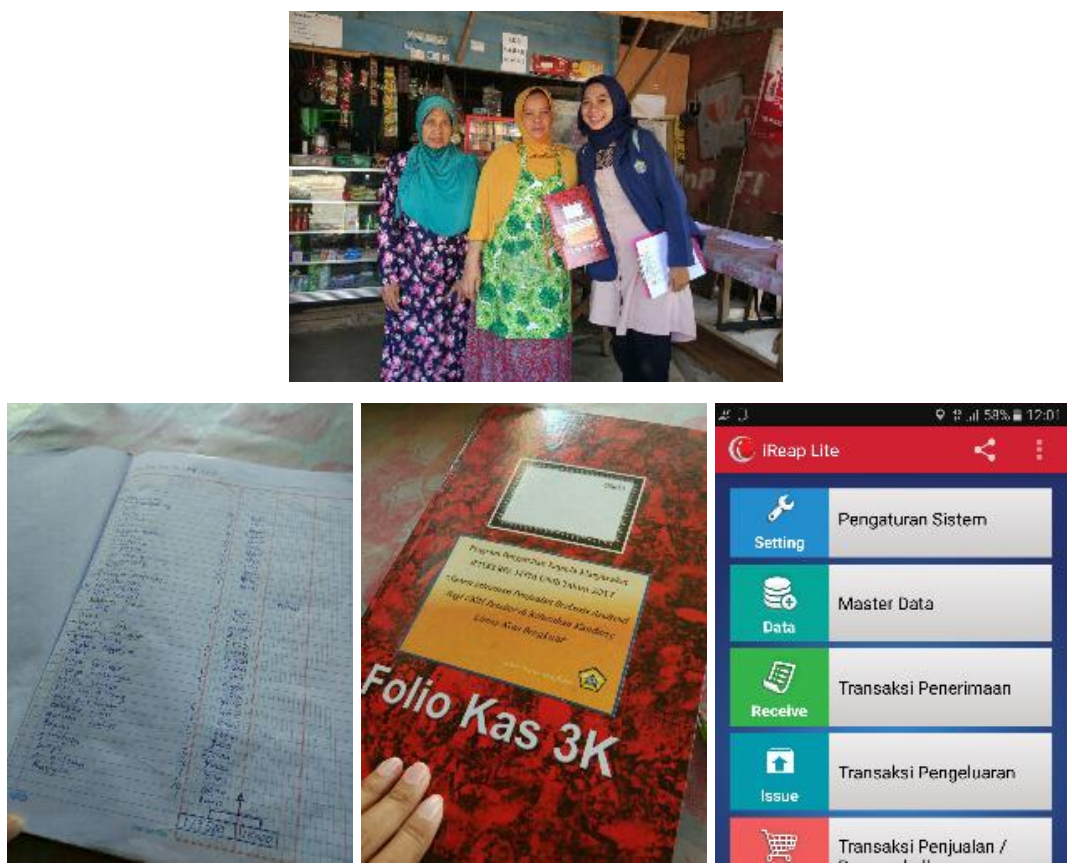

Gambar 4. Monitoring

\section{Evaluasi}

Evaluasi dilakukan pada setiap akhir tahapan program pengabdian, mulai dari penyuluhan, pelatihan sampai praktek penerapan teknologi. Aspek yang dievaluasi adalah kebermanfaatan program, model/metode/cara penyampaian program, sampai kepada keinginan khalayak sasaran untuk menerapkan teknologi secara terus menerus atau hanya sesaat saja, juga pada penilaian seberapa penting teknologi ini untuk diterapkan.

Dari hasil evaluasi Tahap I, dari peserta yang melakukan pencatatan keuangan, 50\% selalu mencatat setiap transaksi uang masuk dan keluar serta transaksi penjualan dan pembelian barang. Mereka juga setiap hari melakukan penjumlahan hasil penjualan, sehingga tahu berapa uang yang berhasil masuk dari aktivitas usaha dagang mereka pada hari itu. Sebelumnya hal ini tidak pernah diketahui. Selain itu, dengan adanya catatan ini, mereka juga menjadi lebih cepat mengetahui jumlah persediaan barang dagangan mereka yang ada di warung. Para peserta juga berpendapat bahwa kegiatan pengabdian ini dinilai bermanfaat, sebanyak $80 \%$ menjawab pertanyaan ini dengan jawaban "ya" dan 20\% tidak menjawab. Ketika ditanya apakah akan tetap melakukan pencatatan keuangan dan berusaha untuk lebih baik dan rapi, dari seluruh peserta yang melakukan pencatatan, $80 \%$ menjawab "ya", dan 20\% tidak menjawab. Pertanyaan terakhir, apakah bersedia mengikuti tahapan pengabdian selanjutnya, 100\% menjawab "ya".

Evaluasi tahap kedua berkaitan dengan pelaksanaan pelatihan instalasi dan penggunaan iREAP. Semua peserta pelatihan melakukan instalasi ke dalam smartphone 
masing-masing, namun hanya 30\% yang menggunakan aplikasi ini dalam aktivtas usaha dagangnya. $70 \%$ lagi tidak menggunakan karena berbagai alasan. Mulai dari alasan terlalu repot sampai kepada HP sering dibawa anak main keluar rumah, sehingga penggunaan tidak efektif. Namun semua peserta menilai bahwa aplikasi ini bermanfaat untuk memperlancar manajemen usaha.

Disamping itu, aspek yang dievaluasi adalah metode penyampaian program. Para khalayak sasaran pengabdian menilai bahwa metode yang digunakan sudah sangat baik, karena menggabungkan antara penyuluhan, praktek dan pendampingan. Sehingga ilmu yang disampaikan bisa benar-benar diserap, dimengerti, dan dijalankan oleh para khalayak. Meskipun sebagian mereka pada akhirnya tidak menggunakan secara rutin teknologi yang diberikan, tapi mereka menilai bahwa secara keseluruhan program ini memberikan manfaat bagi kemajuan usaha dagang mereka.

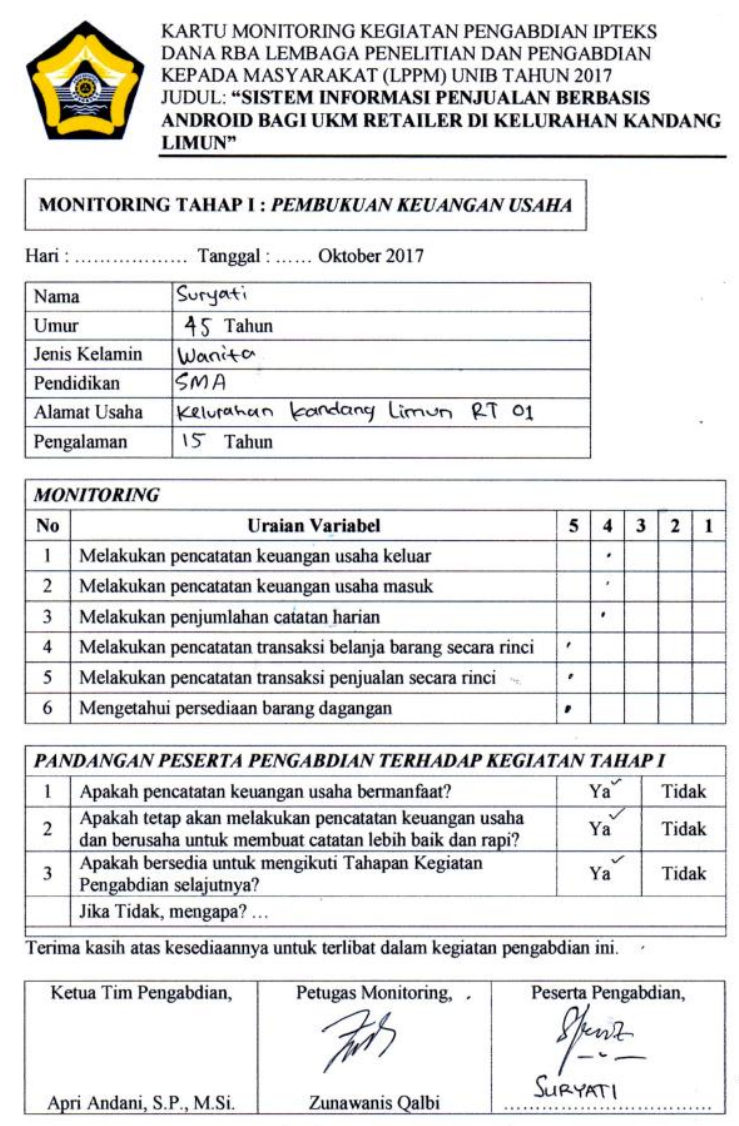

Gambar 5. Salah satu bentuk form evaluasi

\section{KESIMPULAN DAN SARAN}

\section{Kesimpulan}

Dari hasil pengabdian dapat disimpulkan:

1. Terjadi peningkatan kemampuan UKM Retailer dalam memanfaatkan teknologi sederhana untuk kepentingan usaha. Sebelum pengabdian pemilik UKM tidak melakukan pencatatan keuangan, namun setelah pengabdian $50 \%$ peserta sudah melakukan pembukuan keuangan. Berbeda sedikit dengan penggunaan sistem iREAP, 
setelah pengabdian hanya $30 \%$ peserta yang masih menggunakan iREAP untuk pencatatan keuangan, dan $20 \%$ yang menggunakan catatan manual dan iREAP.

2. $100 \%$ peserta pengabdian yang menggunakan catatan keuangan manual dan atau iREAP mampu mengetahui jumlah persediaan dan penjualan usaha dengan sangat baik dibandingkan dengan sebelum mengikuti dan menggunakan teknologi yang diberikan selama pengabdian berlangsung.

\section{Saran}

Adapun yang dapat disarankan dari hasil pengabdian adalah perlunya menanamkan nilai-nilai perubahan, motivasi untuk berubah, dan memanfaatkan teknologi yang dimiliki sebaik mungkin untuk kepentingan usaha yang sedang dijalankan. Penyampaian teknologi saja tidak akan berdampak besar jika pola berfikir masyarakat belum mau diajak untuk berubah.

\section{DAFTAR PUSTAKA}

Anonim, 2017, How to iREAP POS, www.ireappos.com, Diakses pada 13 Juni 2017.

Kandunk, 2014, Pengertian Teknologi Informasi menurut Ahli, Buku, dan Bahasa, www.silontong.com, Diakses pada 12 Juni 2017.

Kirkpatrick, D.L, 1998, Evaluating Training Programs, The Four Levels, Second Edition, Berrett-Koehler Publisher, Inc: San Francisco.

Ladjamudin, Al-Bahra, 2005, Analisis dan Desain Sistem Informasi dan Penjualan. Graha Ilmu: Yogyakarta.

Latifwindar, 2015, Peranan Teknologi Informasi dengan Dunia Bisnis, www.latifwindar.blog.st3telkom.ac.id, Diakses pada 13 Juni 2017.

Pusat Barcode, 2008, Definisi Barcode Scanner, www.pusatbarcode.com, Diakses pada 13 Juni 2017.

Sutarman, 2009, Pengantar Teknologi Informasi, Bumi Kasara: Jakarta. 
72 Dharma Raflesia Unib Tahun XVI, Nomor 1 Juni 2018

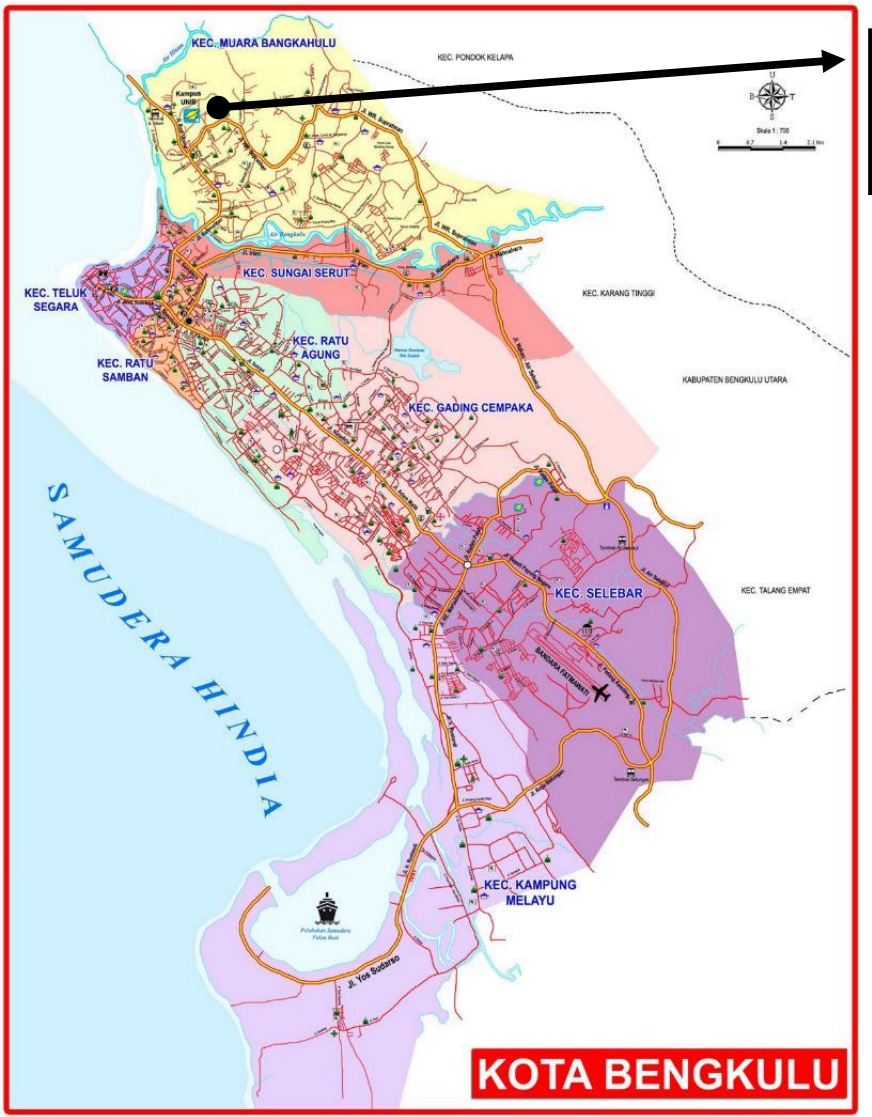

LOKASI KEGIATAN

PENGABDIAN

KEL.KANDANG LIMUN

Peta Lokasi Kegiatan: Kelurahan Kandang Limun, Kec. Muara Bangkahulu, Kota Bengkulu 